\title{
Wealth Inequality and Redistributive Taxation in the Footsteps of Classical Athens
}

\author{
Gerasimos T Soldatos* \\ American University of Athens, Greece \\ *Corresponding author: Gerasimos T. Soldatos, American University of Athens, Greece \\ Submission: 監February 02, 2018; Published: 監 March 13, 2018
}

\begin{abstract}
The general point of this short communication is that wealth redistribution is urgent, it has to start with some initiatives, and that the taxes on immovable property and inheritance would be a good start. This is a lesson derived from the experience of Classical Athens, too.
\end{abstract}

Keywords: Wealth inequality; immovable property and inheritance taxes; Classical athens

\section{Introduction}

Tax reform has always been of policy concern, with the focus on indirect and capital taxes as they are the ones where the trade-off between efficiency and equality applies more relative to progressive income taxation.It is an ongoing discussion in the pursuit of a better tax system, but the rising wealth inequality having accompanied modern globalization, has intensified this discussion. The phenomenon is not new. If empires are seen as globalization cradles, [1] documents that Ancient Rome and Han China were empires of growing economic inequality. And, perhaps this might have been one reason for their eventual fall, having followed more or less the course of Ancient Sparta for which the proverb "Greed will destroy Sparta, nothing else" came true [2]. On the contrary, redistributive taxation in Classical Athens had fostered socio economic cohesion [3]. It is evidenced that democracy played a critical role for this differentiation of Athens, which is logical to expect because in a democracy, the poor can demand and get redistribution from the rich. In an authoritarian regime, only the ruler(s) are in a position to enforce redistribution, but as [4] notes, ruler(s) and the elite have been interwoven ever since the first dramatic wealth inequalities 15000 years ago. The elite was providing gifts for temples, etc., indeed, but i. Re-distributive purposes first appeared in democratic Athens ii. Estate taxation for among other things.

Once the institution of private property was developed, estate taxation in the form of state appropriation of agricultural surplus was already a practice in Greece since Neolithic and Early Bronze Age [5]. It is the redistributive role of this surplus that was advanced in Athens.

The next section describes briefly the increasing wealth inequality of our time and claims that immovable property and inheritance taxation might be used to alleviate and perhaps remedy this inequality in the footsteps of Athens' practices. Section 3 concludes this short note by addressing the reasons why such a policy can promote socio economic stability much like it had done in Ancient Athens.

\section{The Case for Property Taxation}

The source of the alarmingly high wealth inequality that has been documented by [6,7] or [8], among others, and endorsed by [9], nowadays, is again globalization and particularly, financial globalization. Free trade and capital mobility has been weakening the bargaining power of labor, (i) changing thereby pay norms and reducing the role of trade unions, and (ii) scaling back redistributive tax-and-transfer policy [10]. These trends coupled with financial innovation and globalization- which is offering rates of return on financial capital exceeding those on physical capital as predicted by Minsky [11]-have resulted in deteriorating economic performance worldwide save the cases of China and India who are the net beneficiaries of globalization [12]. There are some like [13] who defend the excessive wealth inequality of our times, but they miss the point that what is of policy concern is the nexus between increasing inequality and worsening economic outcomes, and not inequality by itself. It is a concern which puts the matter of capital income taxation, corporate taxation, wealth transfer taxes, and consumption tax on the table for urgent discussion as one of the means that might reverse the deteriorating konjunktur. This matter has a long history that centers upon the precise definitions of the taxes, since assessments of incidence and distortions differ according to definition [14]. But, the feature of taxation which is relevant under the modern extraordinary developments is its redistributive capacity given international capital mobility which allows tax avoidance [6]. (Figure 1) illustrates the inverse trend of 
corporate and sales taxes in Eurozone in response to the increasing ability of capital to avoid domestic taxation through relocation to areas with lower taxes. To prevent capital emigration, the corporate tax rate has been declining and the tax rate on sales has been increasing in order to compensate for the reduction of taxes from corporate income. Thus, redistribution would be served well by taxes on recurrent taxes on immovable property, estate, inheritance, and gift taxes, and taxes on financial and capital transactions, but not by taxes on profits and capital gains of individuals and corporations, which are movable, and by consumption taxes, which are regressive. After all, it is well known that capital income taxes work against the dynamic efficiency of capital accumulation as much as labor income taxes inhibit the dynamic efficiency of the accumulation of human capital embodied in labor [15]. The tax on immovable property is hard to avoid, with relatively low efficiency costs, and positive impact on growth [16]. Estate, inheritance, and gift taxes are quite progressive and their burden cannot be passed on to other agents. And, taxes on financial and capital transactions comprise the renowned Tobin tax [17]. All of them are fair and underutilized save the case of tax on property transfers.These, not sales taxes, are the taxes that should be raised to counter the reduction of corporate taxation. The Tobin tax raises also the issue of the international coordination of the tax authorities, which is a delicate issue because as it was mentioned earlier, there are a few economies that have been favored by globalization. And, one such economy, China, has already enacted a currency transaction tax. European Union too, has approved the introduction of a financial transactions tax as Canada before it, which yet has refrained from putting it into practice for political reasons. The Tobin tax appears to pose little international coordination effort relative to other more complex problems like the adoption of an international cashflow tax on company profit. There appears to be a trade-off between fairness and efficiency depending on where the tax is levied $[14,18]$. The general point of this note is that wealth redistribution is urgent, it has to start with some initiatives, and that the taxes on immovable property and inheritance would be a good start.

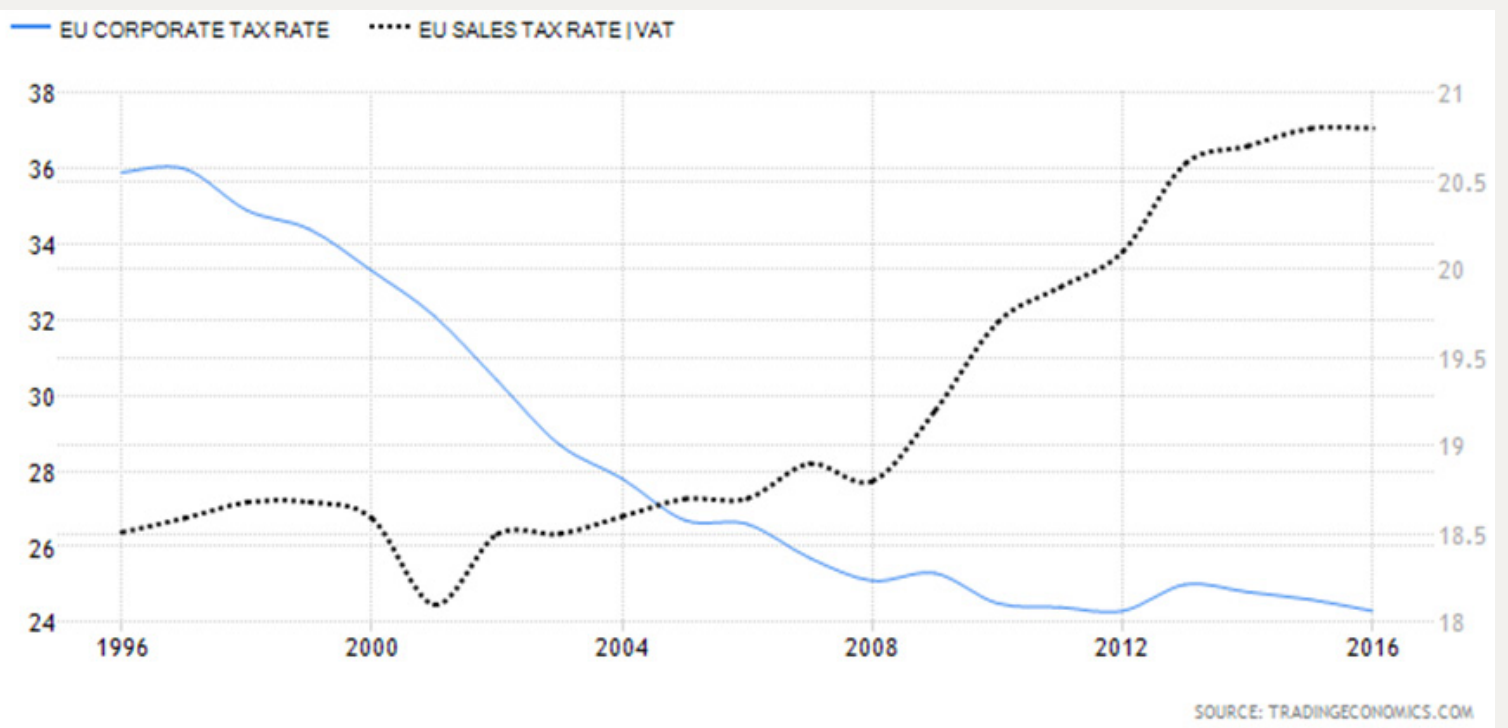

Figure 1: Eurozone VAT and corporate tax rates: 1996-2016.

\section{Concluding Remarks}

The painstaking work of Brady [19] on the history of economic thought and economic history with a focus on Ancient Greece is instructive as to how redistributive estate in general taxation can foster socioeconomic coherence the way it had done in Classical Athens. It "simply" discourages speculation activities on the part of the rich and the subsequent economic instability, encouraging at the same time the consumption of the poor, which consumption may foster growth. But, this policy prescription that has stand the test of time, is blurred by the ideological cloak surrounding the institution of private property and the politico-economic power of large estate owners.

\section{References}

1. Scheidel W (2016) Empires of inequality: Ancient China and Rome.

2. Hodkinson S (2000) Property and wealth in classical Sparta. Duckworth and the Classical Press of Wales, London, UK.
3. Ober (2017) Inequality in late-classical democratic Athens: Evidence and Models. In: Bitros G, Kyriazis N (Eds.), Democracy and an Open Economy World Order. Springer, Netherlands.

4. Kurnick S (2015) The origins of extreme economic inequality: An archaeologist's take on a contemporary controversy. Archaeologies 11(3): 400-416.

5. Given M (2004) The Archaeology of the Colonized. Routledge, New York, USA.

6. Fuest C, Peichl A, Waldenström D (2015) Piketty'sr-g model: wealth inequality and tax policy, CESifo Forum.

7. Pikkety T, Saez E (2014) Inequality in the long run. Science 344(6186): 838-843.

8. Basu K, Stigliz J (2016) Inequality and growth: Patterns and policy. Palgrave Macmillan. New York, USA.

9. OXFAM (2017) An Economy for the 99\%.

10. Atkinson $A B$ (2015) Inequality: What Can Be Done? Harvard University Press, Cambridge, USA. 
11. Mazzucato M, Wray LR (2015) Financing the capital development of the economy: A Keynes-Schumpeter-Minsky synthesis, Levy Economics Institute of Bard College Working Paper No 837.

12. Rodrik D (2017) Populism and the Economics of Globalization, JFK School of Government Working.

13. Mankiw NG (2013) Defending the one percent. Journal of economic perspectives 27(3): 21-34.

14. Auerbach A (2013) Capital income taxation, corporate taxation, wealth transfer taxes and consumption tax reforms. University of Chicago BFI Working Paper. California, USA.
15. Chen BL, Lu CH (2013) Optimal factor tax incidence in two-sector human capital-based models. Journal of public economics 97: 75-94.

16. Norregaard J (2013) Taxing immovable property: revenue potential and implementation challenges.

17. Tobin J (1978) A Proposal for International Monetary Reform. Eastern Economic Journal 4(3-4): 153-159.

18. Auerbach A, Deveraux MP (2015) Cash-flow taxes in an international setting, said business school research paper 3 .

19. Brady ME (2017) From Keynes Back to Smith and Aristotle: Liquidity preference, hoarding, and speculation.

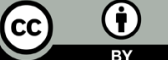

Creative Commons Attribution 4.0 International License

For possible submissions Click Here

\section{Submit Article}

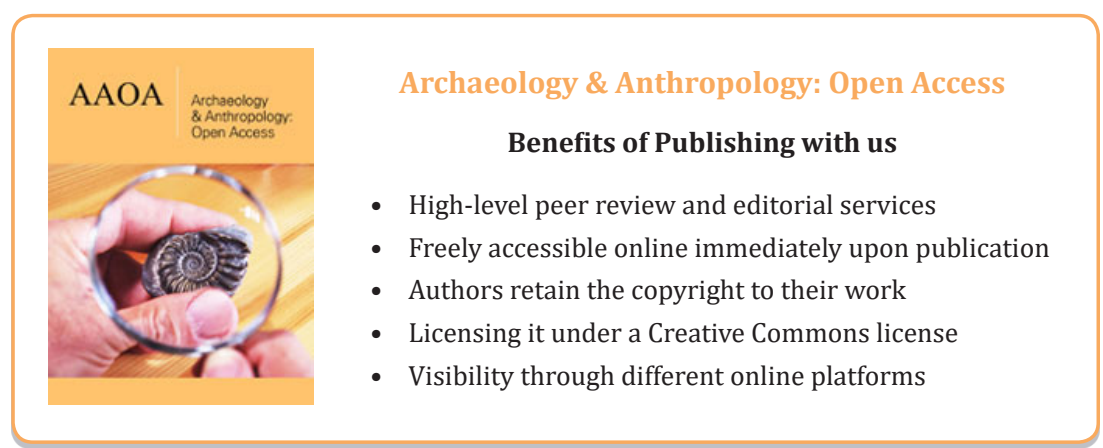

